\title{
ZAKAT AND ECONOMIC DEVELOPMENT: STUDY IN THREE MUSLIM COUNTRIES IN SOUTHEAST ASIA
}

\author{
An'im Kafabih ${ }^{1}$, Setyo Tri Wahyudi ${ }^{*}$ ) \\ Department of Economics Faculty of Economics and Business \\ Universitas Brawijaya, Malang \\ Email: setyo.tw@ub.ac.id*)
}

\begin{abstract}
The objective of this study is to analyze the effect of zakat on per capita income as one indicator of economic development. The data is analyzed by Cobb-Douglas production function and panel data analysis model. Study findings show that zakat significantly and positively affect on per capita income. This study also found that compared to Foreign Direct Investment (FDI), most popular instrument of government to increase economic development, zakat has a greater coefficient. In addition, Muslims as a majority population on average unable to contribute significantly to economic development. However, they could contribute to zakat as seen from increase in amount of zakat collection.
\end{abstract}

Key words: Zakat, per capita income, panel data, FDI

\section{INTRODUCTION}

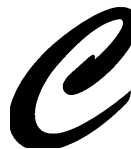
entral Intelligence Agency (CIA) notes that in Southeast Asia there are three countries that have Muslims majority from its population. First is Indonesia with $87.2 \%$ as the largest Muslim Southeast Asia, followed with Brunei Darussalam by $78.8 \%$ and Malaysia with $61.3 \%$.

In addition, total GDP of Indonesia is the largest compared to Malaysia and Brunei Darussalam. Indonesia's GDP in 2015 reached 861.9 billion dollars, while Malaysia and Brunei Darussalam were 296.2 billion dollars and 15.5 billion dollars respectively (World Bank, 2015).

In the late 60s studies conducted by some scholars such as Kindleberger (1958), Higgins (1959) and Krause (1961) emphasized economic growth as a part of economic development of a country. There are relationship between economic development, economic growth, and income per capita. Todaro and Smith (2011) explained that development process is a series of stages in continuous economic growth of all countries. Perkins (2001) explained that economic growth related to per capita income and also an increase in a country's national products. Krause (1961) also defined economic development as an achievement achieved by poor countries to increase their income per capita and their standard of life. Therefore, an indication of economic development can be seen from its economic growth and per capita income. 
Furthermore, as Mankiw (2012) explained, Cobb-Douglas production function is a function that moslty can be used to explain economic growth where only two variables can affect economic growth, viz capital and labor. As capital and labor increase in the same proportion, output will proportionalety also increase.

As capital can be proxied by state of investment because as it will lead to accumulate the state of capital, Solow in his Growth Theory also explains that population is the main source of labor input supply. Based on this explanation, phenomenon of three countries with majority Muslim population will also increase per capita income and also economic development because of its labor-abundance as factor production.

Unfortunately, that analysis only includes these two variables only, whereas In reality, many aspect can also affect economic development. One of them can be religion. As Mirakhor and Askari (2010) explained that economic development process put humans as the end result of process, therefore religion can be included in analysis of economic development because religion can affect human behavior and will determine their state of income as one proxy of human development

Palanca (1986) also notifies that the core analysis in the theory of economic development only includes economic factors such as human resources, natural resources, technology, and capital accumulation but not include non-economic factor such as religion that might influence the state of development .

In 2015, Omar, Hussin and Ali G.H (2015) studied the relationship between Islam and economic development in Malaysia and found that Islam as a religion adopted by majority of population had a significant impact on economic development in the country. As Islam is a second largest religion in the world, Askari, Iqbal, and Mirakhor (2015) explained that Islam is a rule-based system and the state should regulates, supervises and provide incentives for rule compliance.

Furthermore, one compulsory in Islam is zakat payment. Therefore zakat can be used to delineate Islam eventhough it is not sufficient proxy. several verses in Qur'an explain the obligation of a Muslim to pay zakat, such as Al-Anbiya verse 73, Al-Hajj verse 41 and 78, An-Nur's verses 37 and 56 and many more. Theoretically, in the context of economic development, the relationship between zakat and economic development that is proxied by per capita income can be found in explanation of Mariyanti and Mahfudz (2016). They explained that zakat can become the largest source of funding to increase economic empowerment and also as an instrument in order to evenly distribute income to reduce poverty. Therefore, increasing zakat will also relate to the increase in income of poor people.

Chodhury (1986) showed that higher zakat will affect to per capita income through higher investment. In addition, Mahat and Warokka (2013) showed that zakat is an instrument that will increase economic growth. Toor and Nasar (2004) evaluated zakat as a social safety net program from Pakistan government. They found several things that must be addressed in zakat management to improve social welfare. 
Based on that brief explanation, the main objective of this study is to analyze the effect of Islam that is proxied by zakat on economic development. Solow growth model is used to be modified to include religion factors to affect economic development.

\section{RESEARCH METHOD}

We use the Cobb-Douglas production function with further modification below to illustrate the Solow neoclassical growth model.

$$
F(K, L)=A K \alpha L 1-\alpha
$$

Makniw (2012) explained that $\mathrm{A}$ is a parameter, the value is greater than zero, $\mathrm{K}$ is capital accumulation and $\mathrm{L}$ is labor force. This study uses FDI as a proxy for capital accumulation as presented by Todaro and Smith (2011). The uniqueness of Solow growth model to differentiate it from other growth theories is the model proposed by Solow can be modified by incorporating technology as an exogenous variable (Mankiw, 2012).

Mankiw (2012) explains that technology leads labor to be more efficient. Technology cab be knowledge or insight that is owned by community about the production process. As technology increase, efficiency also increase. Furthermore, in Solow growth model, labor input is from population growth, therefore the population is a main source of labor (Aghion and Howitt, 1999). Based on this concept, this study tries to specify the existing Muslim populations only. This is because the Southeast Asian countries observed in this study have the largest Muslim population and aim to see the contribution of Muslims as a population to economic development proxied by income per capita. Furthermore, Palanca (1986) and Wan Omar et al (2015) showed that Islam can affect economic development. We include Islam, which is proxied by zakat to be analised on its relationship to economic development.

This study uses balanced panel data that combine cross-section and time- series (Matyas and Sevestre, 1996). We use data from 3 countries with largest Muslim population in Southeast Asia (Indonesia, Malaysia, and Brunei Darussalam) with 11-year time series for each country, starting from 2004-2014. The total observations are 33. Bolstad (2007) explained that minimum observation was 25 ( $n \geq 25$ ).

The advantage of panel data is to reduce multicollinearity problems and eliminate or reduce bias (Matyas and Sevestre, 1996). collected data will be analyzed by eviews program. The data in this study have larger number of time series than the parameters. Based on Ekananda (2014) and Gujarati and Porter (2009), we use Fixed Effect Model (FEM) and to determine the heterogeneity of each characteristic of the countries, this study uses fixed effect least squares dummy variability (LSDV) (Gujarati and Porter, 2009). Furthermore, because this study uses the Cobb- Douglas production function that not linear, according to Gujarati and Porter (2009), model can be transformed into a logarithmic equation, so that model in this study can be written as follows,

$$
\text { InYit = In a0 +a1 D1i + a } 2 \text { D2i + a3 In CAPit + a4 In MPOPit+ a5 In Rit + et ....(2) }
$$

Where, 


\begin{tabular}{|l|l|l|}
\hline Notation & Operational Definition & Proxies \\
\hline Y & $\begin{array}{l}\text { Economic growth as an indicator of } \\
\text { economic development }\end{array}$ & GDP per capita \\
\hline CAP & Capital Accumulation & FDI \\
\hline MPOP & Muslim Population as labor supply & Muslim Population \\
\hline R & Islam & $\begin{array}{l}\text { Total accumulation } \\
\text { accat }\end{array}$ \\
\hline e & Error term & - \\
\hline ao..5 & Constanta & - \\
\hline i & Individual data & - \\
\hline t & Time series data & - \\
\hline
\end{tabular}

Source : researcher, 2016

For dummy variable (D), Dummy 1 (D1i) = 1 for Brunei Darussalam, and 0 for others, Dummy $2(\mathrm{D} 2 \mathrm{i})=1$ for Indonesia, and 0 for others, and 0 for Malaysia.

\section{RESULT AND DISCUSSION}

Data in this study is taken from World Bank, CIA, National Amil Zakat Agency (BAZNAS), MUIB (Brunei Islamic Religious Majlis), Malaysia Zakat Collection Center, and others. The graph 1 illustrates the state of zakat and per capita income in three countries with largest Muslim population in Southeast Asia.

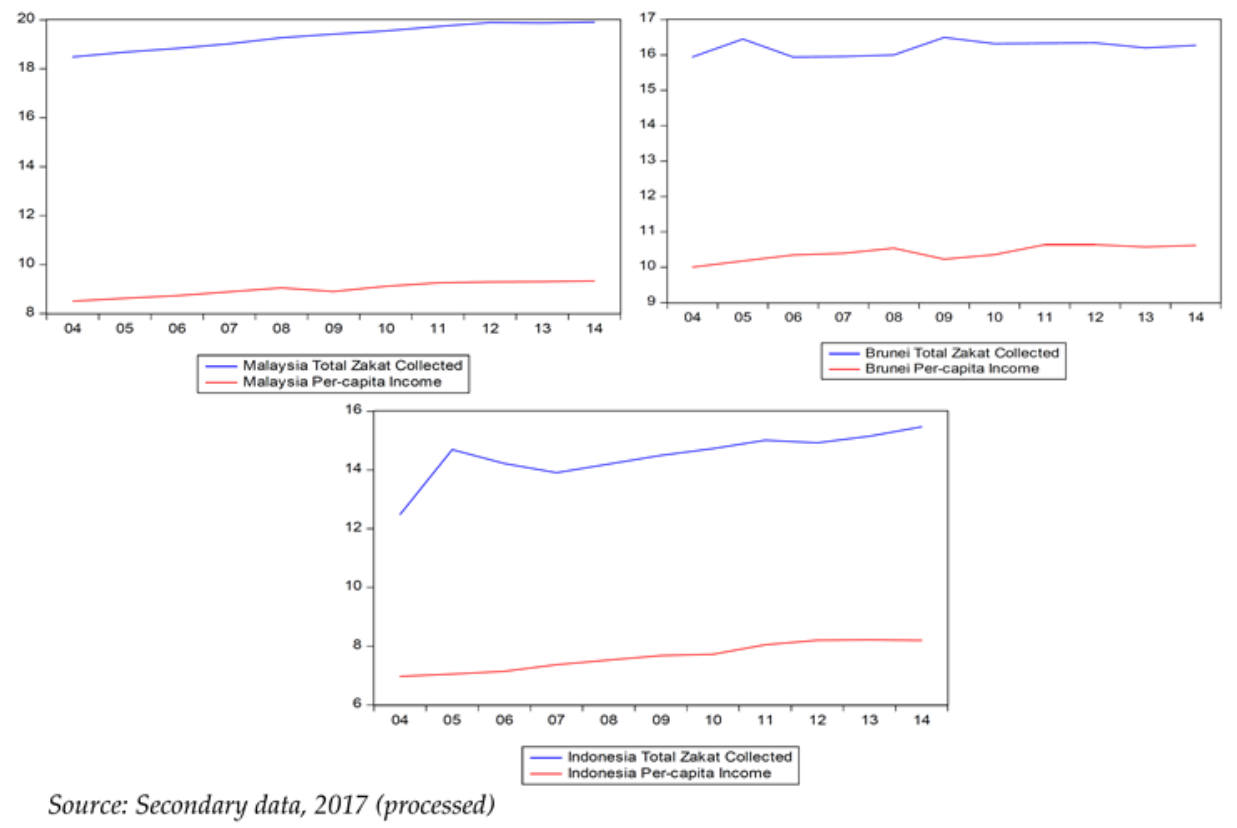

Figure 1. Zakat And Per Capita Income In Three Countries 
Figure 1 shows trend in all three countries that show increase in both capita income and in zakat collection. Per capita income in Indonesia continues to increase with less volatile rate compared to Brunei Darussalam. Year 2009 showed a decrease in per capita income. While per capita income in Malaysia shows the same trend with Indonesia.

Total amount of zakat collected in Indonesia and Brunei shows quite volatile while Malaysia shows a steady increase from 2004 to 2014. Indonesia has a peak increase in its zakat collection in 2006 and followed by a sharp decline until 2008, after that year, zakat collection in Indonesia showed stable upward trend. The collection of zakat in Brunei slight fluctuated and also in Malaysia.



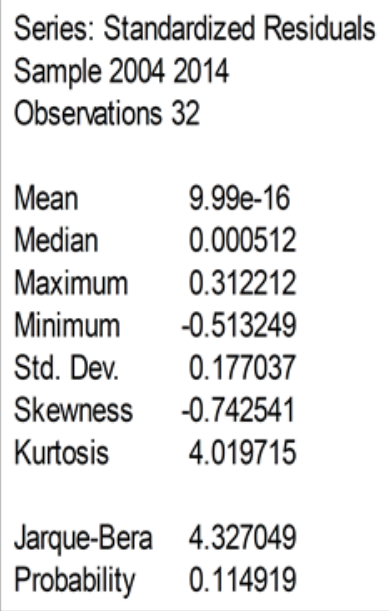

Figure 2. Jarque-Bera Normality test

Normal distribution of data is shown by Jarque-Bera test as it is showed in figure 2 . The result show a probability value of 0.11 . It can be concluded that error terms are normally distributed. In table 3, R-square shows 0.978. It means that on average, all observed variables are able to affect per capita income by $98 \%$, while other $2 \%$ is explained by other variables outside the model. The dummy variable results are shown in table 1 and table 2.

Table 1 Percentage coefficients for each country

\begin{tabular}{|c|c|c|c|c|}
\hline & & Country & Coefficient & \multirow{3}{*}{$\begin{array}{c}\text { Value (\%) } \\
\text { Darussalam }\end{array}$} \\
\hline & & -6.856 & \multirow{2}{*}{-6.9 Brunei Darussalam } & \\
\hline & & 4.328 & & \\
\hline Indonesia & 0.782 & -6.1 & & \\
\hline
\end{tabular}

Source: Secondary data, 2017 (processed)

Table 1 shows Malaysia, Brunei Darussalam and Indonesia have a negative slope, meaning that there is no increase in FDI, Muslim population, and zakat, or if all variables observed in this paper are to be constant, per capita income of each country will tend 
to decrease. Malaysia decrease by $6.9 \%$, Brunei Darussalam by $2.5 \%$ and Indonesia by $6.1 \%$.

Table 2 Percentage coefficients for each country

\begin{tabular}{lll}
\hline Variables & Coefficient & Probability \\
\hline Capital Accumulation (FDI) & 0.100 & 0.01 \\
Muslim Population (MPOP) & 0.241 & 0.32 \\
Islam (R) & 0.499 & 0.00 \\
\hline
\end{tabular}

Source: Secondary data, 2017 (processed)

Table 2 shows hypothesis testing for each variable independently. Among the three variables observed, only Muslim population variable (Mpop) is not significant in any level while FDI and Zakat variables are significant.

Table 3. Table of regression with fixed effect model Least Squares Dummy Variable (LSDV)

Dependent Variable: $Y$

Variable

Coefficient Std. Errort-Statistic Prob.

\begin{tabular}{lllll}
\hline DUMMY_1*** & 4.328212 & 1.120728 & 3.861966 & 0.0007 \\
DUMMY_2* & 0.782489 & 0.458267 & 1.707496 & 0.0996 \\
CAP** & 0.100441 & 0.038859 & 2.584740 & 0.0157 \\
MPOP & 0.241045 & 0.242132 & 0.995508 & 0.3287 \\
R $^{* * *}$ & 0.499720 & 0.091942 & 5.435168 & 0.0000 \\
C & -6.8563964 .343219 & -1.578644 & 0.1265 \\
\hline R-squared & 0.976448 Mean dependent var & 9.083374 \\
Adjusted R-squared & 0.971919 S.D. dependent var & 1.153589 \\
S.E. of regression & 0.193311 Akaike info criterion & -0.281668 \\
Sum squared resid & 0.971602 Schwarz criterion & -0.006843 \\
Log likelihood & 10.50669 Hannan-Quinn criter. & -0.190571 \\
F-statistic & 215.5898 Durbin-Watson stat & 1.221818 \\
Prob(F-statistic) & 0.000000 & & \\
\hline
\end{tabular}

Based on Table 1, without any additional investment, Muslim population, and zakat, then the state of development as proxied by per capita income of each countries on average tend to decrease. Based on table 2, FDI and zakat have positive and significant relation to economic development, but not for Muslim population variable.

Zakat and FDI have different coefficients. The coefficient value can be interpreted that average increase in zakat by $1 \%$ will increase per capita income by $0.5 \%$, and an increase in average on FDI of $1 \%$ will increase the average income per capita by $0.1 \%$. The amount of zakat contribution to per capita income as an indicator of economic development

QE Journal | Vol.09 - No.01 - 6 
when compared to FDI can produce a recommendation to government to pay more attention to zakat as an instrument to increase per capita income as an indicator of economic development rather than focusing to attract foreign investors to invest in the form of FDI.

These results consistent with Mahat and Warokka (2013) showing that zakat can become a major source of economic growth and can become domestic direct investment rather than Foreign Direct Investment. It is currently a highly regarded instrument for development in developing countries. In addition, this study consistent with Ahmed (2008) that zakat is an instrument to reduce poverty levels, one of which is an increase in per capita income to shows indicators of economic development.

This study also finds that Muslim population is not significant to affect per capita income. It can be interpreted that on average the Muslim population has a very small contribution to economic development. Solow neoclassical growth model explains that population is the labor itself because the labor supply is the population. This means that labor will affect the economic development, but insignificant results on Muslim population variables indicate that possibility of Muslims in three countries being observed does not work as labor. Therefore, increasing trend of zakat in 3 countries and explains that Muslims do not contribute to being a workforce which will increase economic development. Future research should answer questions from where the sources income of Muslim populations so that they are able to pay zakat as an obligation in Islamic teachings.

There is another possibility to explain the small contribution of Muslim communities to economic development, namely the existence of unemployment and poverty. We suggest a new view in looking at economic development as suggested by Oladapo and Rahman (2016) to explain the main determinants of human development as the ultimate goal of economic development based on maqasidal Shari'ah, namely, social justice, human rights human, education, health, and income. In addition, Oladapo and Rahman (2016) also explain latent factors that must also be considered in development are gender, marital status and religious beliefs..

\section{CONCLUSIONS AND RECOMMENDATIONS}

\section{Conclusion}

Per capita income should be concerned as an indicator of economic development. This study shows that zakat has a positive and significant effect on economic development. Furthermore, zakat has a greater impact on development than FDI. Therefore, zakat can be used as a reference in economic development rather than FDI where many developing countries used it as the main instrument to improve economic development. This study also found that Muslims as the majority population on average were unable to contribute significantly to economic development, but on other hand, zakat showed an increasing trend so further research was needed on source of income to pay zakat. Another possibility that arises from small contribution of majority of Muslim population to economic development is that there is still unemployment and poverty. 


\section{REFERENCES}

Ahmed, Habib. Zakah, macroeconomic policy, and poverty alleviation: lesson from simulation on bangladesh. Journal of Islamic Economics, Banking and Finance. (2008), 4(2). Pp. 81-105.

Agion, Philippe \& Howitt, Peter. (1999). Endogenous growth theory. London : The MIT press.

Askari, Hossein., Iqbal, Zamir \& Mirakhor, Abbas. (2015). Introduction to Islamic Economics: theory and application. John Wiley\&Sons: Solaris South Tower.

Bolstad, William M. (2007). Introduction to Bayesian Statistics (2nd ed.). New Jersey: Joh Wiley \& Sons.

Choudhury, Masudul Alam. (1986). Contributions to Islamic Economic theory: A study in social economics. Palgrave Macmillan: New York.

Ekananda, Mahyus. (2014). Analisis ekonometrika data panel bagi penelitian ekonomi, manajemen, akuntansi. Jakarta: Mitra Wacana Media.

Gujarati, Damodar N. \& Porter Dawn C. Basic Econometrics (5th Ed). New York : McGraw-Hill Irwin

Higgins, Benjamin. (1959). Economic Development: Principles, Problems, and Policies.USA : The Vail-Ballou Press.

Kindleberger, Charles P. (1959). Economic Development : Asian Students' Edition. Japan: McGraw-Hill.

Krause, Walter. (1961). Economic Development. San Fransisco: Wadsworth Publishing Company

Mahat, Nor Idayu and Warokka, Ari. Investigation on zakat as an indicator for moslem countriess economic growth. J. Global Business Advancement. (2013). Vol. 6, No. 1. Pp. 50-58.

Mankiw, N. Gregory. (2012). Macroeconomics (8th ed.). New York : Worth Publisher.

Mariyanti, Tatik \& Mahfudz Akhmad Affandi. Dynamic circular causation model in poverty alleviation: Empirical evidence from Indonesia. Humanomics.(2016). Vol. 32 No. 3. Pp. 275-299.

Matyas, Laszlo \& Sevestre, Patrick. (1996). The economitrics of panel data : A handbook of theory and application (2nd ed.). Dordrecht: Kluwer Academic Publisher.

Mirakhor Abbas \& Askari, Hossein. (2010). Islam and The Path to Human and Economic Development. New York : Palgrave Macmillan.

Oladapo, Ibrahim Abiodun \& Rahman Asmak Ab. Re-counting the determinant factors of human development: a review of the literature. Humanomics. (2016). Vol. 32. No. 2. Pp. 205-226. 
Omar, W.A. Wan., Hussin, Fauzi., \& G.H, Asan Ali. The Trend Analysis of Islamization in Malaysia Using Islamization Index As Indicator. Asian Economic and Financial Review. (2010). Pp. 1298-1313.

---. The Empirical Effect of Islam on Economic Development in Malaysia.

Research in World Economy. Vol. 6. No. 1. (2015). Pp. 99-111.

Palanca, Ellen H. Religion and Economic Development. Philippine Studies, Vol. 34, No. 2 (Second Quarter 1986), pp. 162-180.

Perkins, Dwight H., Radelet, Steven., Snodgrass, Donald R., Gillis, Malcolm., Roemer, Michael. (2001). Economic Development(5th ed.). United Stated of America: Norton \& Company.

Todaro, Michael P. \& Smith, Stephen C. (2011). Economic Development (11th ed.). Boston: Pearson Education.

Toor, Imran Ashraf and Nasar Abu. Zakat as social safety net : exploring the impact on household welfare in Pakistan. Pakistan Economic and Social Review Vol. XLII, No, $1 \& 2$ (2004), pp. 87-102. 